\title{
REVIEW OF THEORY OF MULTIPLE INTELLIGENCES
}

\author{
Anmol \\ PhD JRF Scholar \\ Post Graduate Department of Psychology \\ Ravenshaw University, Cuttack, Odisha, India
}

\begin{abstract}
This paper reviews the contribution of Dr. Howard Gardner and his proposed theory of multiple intelligences. Dr. Howard Gardner rejected the existing models of measurement of intelligence that was based on narrow and limited definition. His theory of multiple intelligences encourages the various stakeholders to consider all the dimensions of intelligence that may be present in a student before accessing and grading them. This paper analyses the various components of Gardner's theory. An attempt has been made to integrate the various findings from the existing review of related literature to present a holistic view about the practical applications of Gardner's theory. Various examples have been used to demonstrate the process of integration of Gardner's theory in the classroom. The paper concludes with the present outlook of Gardner's theory and how the teachers and instructors can use the concepts of this theory to increase the engagement of students in the classroom. Suggestion for future studies is also provided.
\end{abstract}

Keywords-Multiple Theory of Intelligence, $g$ factor theory, Naturalist intelligence, Pedagogy

\section{INTRODUCTION}

Intelligence refers to intellectual functioning [1]. Intelligence has been defined in several ways by researchers. Dr. Howard Gardner of Harvard University proposed a holistic view of intelligence. He proposed his idea of multiple intelligence in 1983 in his book- "Frames of mind: The theory of multiple intelligence" [2]. Gardener was not satisfied with existing models of measurement of IQ because he believed that the existing IQ tests were based on narrow definitions [3]. Thus, if a student was good at maths, then as per the existing definitions he was considered to be more intelligent than others who are not good at maths. A critical analysis of the theory of multiple intelligences points towards the novel approach of Gardener to devise an unbiased theory of intelligence [4]. Identification of various forms of intelligence is therefore critical in acknowledging the skills of those students who may not be good at logical or mathematical reasoning, but none the less perform better on other domains of intelligence.

\section{RATIONALE OF THE STUDY}

There is a lack of review of literature devoted to the investigation of the integration of Gardner's theory with teaching-learning methods in the classroom. A host of existing literature is rich in documenting the various concepts of Gardner's theory of multiple intelligences. However, more research studies are required to conclude about the practical applications of the Gardner theory. This paper attempts to highlight the various components of Gardner's theory of multiple intelligences and also aims to integrate Gardner's theory with the existing pattern of education.

\section{REVIEW OF LITERATURE}

Gardner's theory of multiple intelligence suggests that the traditional notion of intelligence based on IQ testing is far too limited [2]. Instead, Dr. Gardner proposes eight different types of intelligence to measure the dynamics of human intelligence. The eight multiple intelligences are verbal-linguistic intelligence, logical and mathematical intelligence, visualspatial intelligence, bodily-kinesthetics intelligence, musicalrhythmic intelligence, interpersonal intelligence, intrapersonal intelligence, naturalist intelligence [5].

\section{A. Verbal linguistic intelligence}

People possessing verbal-linguistic intelligence are smart in vocabulary and the use of words [5]. Such people have exceptional abilities to read or write it and also the ability to speak well. Generally, such people prefer professions that includes acting, journalism, and so on. Example of some of the personalities who can be proposed to be rich in the above domain of intelligence includes Mark Twain (a famous writer of children stories), Robert Frost (a famous poet), RK Narayan (a famous writer and creator of fictional characters for children) and so on.

\section{B. Logical or mathematical intelligence}

People rich in this domain of intelligence are smarter at dealing with numbers. Such people generally follow a more logical approach to problem-solving as compared to others [6]. The preferable profession for people possessing logical or mathematical intelligence can include the profession of accountants, data analyst, statisticians, and so on. Example of 


\section{International Journal of Engineering Applied Sciences and Technology, 2019 Vol. 4, Issue 3, ISSN No. 2455-2143, Pages 492-495 \\ Published Online July 2019 in IJEAST (http://www.ijeast.com)}

some of the personalities who can be proposed to be rich in the above domain of intelligence includes Albert Einstein ( known for his complex problem solving skills related to Physics and Mathematics [7] ), Raghuram Rajan ( a famous economist and the ex-RBI Governor of India), Alan Turing ( a famous computer scientist [8]) and so on.

\section{Visual-Spatial intelligence}

Individuals having visual-spatial intelligence are good at imagining a picture and can draw well [6] . The distinct characteristic of such people is the ability to represent and relate thoughts with pictures [9]. The preferable profession of such people can include careers in the animation industry, architectures, cartoonist, and so on. Example of some of the personalities who can be proposed to be rich in the above domain of intelligence includes Walt Disney (the creator of famous Mickey Mouse cartoon series), M.F. Hussain (a famous painter from India) and so on.

\section{Bodily-kinesthetics intelligence}

The core aspects include smooth control of one's bodily motions and the capacity to handle objects skillfully [10]." Professions preferred by people rich in bodily-kinesthetic intelligence includes gymnastics, choreography, athletics and sports, and so on. Examples of some of the personalities who can be proposed to be rich in the above domain of intelligence includes Michael Phelps (a famous Olympic swimmer), Michael Jackson (the king of pop music and pop dance [11]) and so on.

\section{E. Musical-rhythmic intelligence}

People possessing musical or rhythmic intelligence are smart at composing music and playing musical instruments [12]. Such people prefer professions related to music composing, instrument playing, singing and so on. Examples of some of the personalities who can be proposed to be rich in the above domain of intelligence includes Beethoven (a famous piano player and music composer), Pandit Ravi Shankar (famous as flute player), Lata Mangeshkar (famous singer and music composer) and so on.

\section{F. Interpersonal intelligence}

People high on interpersonal intelligence can connect easily with others and are generally sensitive to the moods and feelings of others [3]. Such people also like to work as a part of a group. They often enjoy discussions and debate. Such people follow professions related to politics, therapist, counsellors, and so on. Examples of some of the personalities who can be proposed to be rich in the above domain of intelligence includes Sigmund Freud ( famous for his contribution to counselling [13]), Aaron Beck ( the founder of cognitive-behavioural therapy [14]), Shri Narendra Modi ( Prime Minister of India and globally, a very famous personality [15]) and so on.

\section{G. Intrapersonal intelligence}

People with intrapersonal intelligence are self-smart individuals [16]. In other words, such individuals have a deeper understanding of the self and are also aware of their strengths and weaknesses [2]. Individuals with intrapersonal intelligence are also able to predict and control their reactions and emotions. Examples of some of the personalities who can be proposed to be rich in the above domain of intelligence includes Carl Rogers ( founder of the humanistic school of thought [17]), Abraham Maslow ( famous for the theory called as " Maslow hierarchy of needs" [18]) and so on.

\section{H. Naturalistic intelligence}

People possessing naturalistic intelligence are called to be nature smart people. It is to be noted that the component of naturalist intelligence was not a part of Gardner's original Theory of Intelligence [2]. The initial theory proposed by Gardner, composed of seven components. The last component, the component of naturalist intelligence was added by him in the theory of multiple intelligence in 1995 [3]. Gardner argues that, an individual who can recognize flora and fauna and use his abilities efficiently in the processes of hunting, farming, harvesting, and so on is also exercising an essential form of intelligence [3]). Gardner describes this kind of intelligence as naturalist intelligence. People with naturalist intelligence prefer professions related to agriculture, geology, archaeology, and so on.

1) Integrating Gardner's multiple intelligence theory with pedagogy

Gardner proposes that elements of teaching should be related to dimensions of multiple intelligences so that every student can relate to the teaching-learning process based on their type of intelligence [19]. Let us take an example to demonstrate the integration of Gardner's theory of multiple intelligence with teaching methods in a classroom [20]. A chemistry teacher wishes to teach about the chapter of carbon to his students. Reading about the carbon will stimulate the verbal and linguistic form of intelligence. When it comes to the logical and mathematical form of intelligence, the use of chemical equations related to the carbon chapter will be beneficial. For the students who relate more to visual form of intelligence, the instructor can present pictures of carbon, like 3D models or animated models of the various forms of carbon available in nature. Students who relate more to musical-rhythmic domain of intelligence might find it easier to relate to the carbon chapter if the teacher encourages the student to compose music and mnemonics related to the properties of carbon. For those students who relate more to the interpersonal domain of intelligence, the teacher can ask the students to make groups and debate on various characteristics of carbon. The intrapersonal domain of intelligence stimulates the need for contemplation and philosophical reasoning in an individual. Therefore, a teacher can ask the students to analyse the importance of carbon and its contribution to the origins of life on planet Earth. For the students who relate more to the 


\section{International Journal of Engineering Applied Sciences and Technology, 2019 \\ Vol. 4, Issue 3, ISSN No. 2455-2143, Pages 492-495 \\ Published Online July 2019 in IJEAST (http://www.ijeast.com)}

experiences in the natural world, the teacher can take the students on trips to carbon mines or factories where various forms of carbons are processed. While using the above techniques, it is essential to know that no single approach is suitable for all the students. Further, the impact of teaching methods can vary from one culture to another culture. Therefore, while integrating the Gardener's theory of multiple intelligence with teaching-learning processes in classrooms, it is crucial for the instructor or for the teacher to take individual differences in the account [19].

\section{2) Present Outlook of Gardener's Theory}

Perhaps the most significant impact of Gardner's theory is revolutionizing the traditional teaching methods [19]. Dr. Gardner says that more reinforcement is provided to students good at the linguistic and or logical and mathematical domains of intelligence [6]. However, students good at other dimensions are left out and are misappropriated labelled as underachievers. Hence Gardener encourages to encompass all the dimensions of intelligence that may be present in a student before assessing or teaching the student. A direct outcome of Gardner's theory of multiple intelligences is that it attempts to break the notion of biased measures of intelligence tests [21]. Therefore, parents who complain about their children not being good at subjects related to maths or science can learn to acknowledge the potential of their children in other domains of intelligence. Similarly, the notion that a student from a science stream is more intelligent than a student from the arts stream is also questionable in the context of Gardner's theory.

\section{CONCLUSION}

The paper reviewed the theory of multiple intelligences proposed by Dr. Howard Gardner. Gardner proposes that there are eight different domains of intelligence, and all such domains of intelligence should be given due importance while assessing the students. Multiple intelligence includes verballinguistic intelligence, logical-mathematical intelligence, visual-spatial intelligence, bodily-kinesthetic intelligence, musical-rhythmic intelligence, interpersonal intelligence, intrapersonal intelligence, and naturalist intelligence [2]. For the stimulation of verbal and linguistic intelligence, the instructor should focus more on activities related to comprehension and reading [20]. Similarly, numbers and equations should be used while relating to logical and mathematical intelligence [22]. Use of pictures and symbols can stimulate the visual domain of intelligence [22]. When it comes to the domain of bodily-kinesthetic intelligence, an exposure to physical experiences will work better than the passive form of teaching in a closed setup [6]. Exposure of students to music and lyrics will help them to relate to the musical and rhythmic domain of intelligence [12]. When it comes to the interpersonal domain of intelligence, the instructor can use discussions and debate and increase the students to participate in various forms of social interactions [19]. Intrapersonal intelligence is related to awareness about the self, and therefore, encouragement of contemplation techniques can stimulate the intrapersonal domain of intelligence [5]. For stimulating the naturalist domain of intelligence, exposure of the students to natural settings or environment will be beneficial [3]. It is concluded that Gardner's theory of multiple intelligences has lots of potentials when it comes to revolutionizing the traditional teaching methods. As indicated earlier, a teacher can use the concept from Gardner's theory to increase the engagement of the students in a classroom. It is worthwhile to note here that a single theory cannot always be applicable in its generic form to different cultures. Therefore, future studies should be conducted to investigate the adaptation of Gardner's theory to different cultures all over the world.

\section{REFERENCES}

[1] "Intelligence." [Online]. Available: https://www.apa.org/topics/intelligence/index.

[Accessed: 30-Jul-2019].

[2] J. Tropman and H. Gardner, "Frames of the Mind: The Theory of Multiple Intelligences," J. Policy Anal. Manag., vol. 4, no. 3, p. 476, 1985.

[3] H. Gardner, Intelligence reframed. 1999.

[4] L. S. Almeida, M. D. Prieto, A. I. Ferreira, M. R. Bermejo, M. Ferrando, and C. Ferrándiz, "Intelligence assessment: Gardner multiple intelligence theory as an alternative," Learn. Individ. Differ., 2010.

[5] H. Gardner, "Intelligence reframed: Multiple intelligences for the 21 st century," Intell. reframed Mult. Intell. 21 st century, no. Mi, pp. X, 292 S., 1999.

[6] Frames of mind: the theory of multiple intelligences. New York: Basic Books, 2011.

[7] L. P. Pitaevskii, "The great physicist," Her. Russ. Acad. Sci., 2008.

[8] A. M. Turing, "Computing machinery and intelligence," in Parsing the Turing Test: Philosophical and Methodological Issues in the Quest for the Thinking Computer, 2009.

[9] S. Wax and H. Gardner, "Intelligences, Multiple," in Encyclopedia of Sciences and Religions, 2013.

[10] "Multiple intelligences: the theory in practice," Choice Rev. Online, 2013.

[11] S. Tenenbaum, "I Know I Am Someone: Michael Jackson, 'Thriller', and American Identity," 2011.

[12] H. Gardener, "Musical Intelligence," Fram. Mind. Theory Mult. Intell., 2004.

[13] D. Westen, "The Scientific Legacy of Sigmund Freud: Toward a Psychodynamically Informed Psychological Science," Psychol. Bull., 1998.

[14] J. Scott and A. T. Beck, "Cognitive behavioural therapy," in Essential Psychiatry, Fourth Edition, 2008.

[15] "DNA Edit: Dizzying popularity - Modi's global image is touching new highs." [Online]. Available: https://www.dnaindia.com/analysis/editorial-dna-editdizzying-popularity-modi-s-global-image-is-touching- 
new-highs-2777089. [Accessed: 30-Jul-2019].

[16] W. M. Lynch, "Multiple Intelligences," Teach. Educ., 1995.

[17] B. Thorne and P. Sanders, Carl rogers. 2013.

[18] A. Cordell, I. Thompson, A. Cordell, and I. Thompson, "Maslow's Hierarchy of Needs," in The Procurement Models Handbook, 2019.

[19] R. Joneja, "Study of Multiple Intelligences Model of Howard Gardner in Higher Education," WeSchool, 2016.

[20] T. Lintner, "Multiple Intelligence and the Studying of the Civil War: Theory into Practice.," South. Soc. Stud. J., 2002.

[21] H. Gardner and T. Hatch, "Educational Implications of the Theory of Multiple Intelligences," Educ. Res., 1989.

[22] P. Stanford, "Multiple Intelligence for Every Classroom," Intervention in School and Clinic. 2003. 